\title{
Monitoring the Hepatitis A Virus in Oyster from Korea
}

\author{
Sanghun Park1, Hyowon Jeong1, Jihun Jung1, Kyungsik Kim¹, Sungkyu Park1, Musang Kim¹, \\ Yeonsun Kim², Younghee Oh1, Kweon Jung1 \\ ${ }^{1}$ Infectious Disease Research Division, Seoul Metropolitan Government Research Institute of Public Health and \\ Environment, Gwacheon-si, Korea \\ ${ }^{2}$ Department of Public Health, Graduate School Dankook University, Seoul, Korea \\ Email: sanghun93@seoul.go.kr
}

Received 10 November 2015; accepted 6 December 2015; published 9 December 2015

Copyright $(2015$ by authors and Scientific Research Publishing Inc.

This work is licensed under the Creative Commons Attribution International License (CC BY).

http://creativecommons.org/licenses/by/4.0/

(c) ()

\begin{abstract}
Hepatitis A virus (HAV) causes many cases of oyster- or clam-associated gastroenteritis in various countries. HAV was detected on oyster by RT-PCR in $19.6 \%(11 / 56)$ in Korea. The percentages of HAV-positive samples in 2011 and 2012 were $27.6 \%$ and $11.1 \%$, respectively. Phylogenetic analysis revealed that several nucleotide sequences highly similar to those of HAVs isolated in this study. Phylogenetic analysis of the coding regions of the viral protein VP4/VP2 revealed that all amplicons were classified into IA genogroup. It will provide useful data that aids in our understanding circulating HAVs and may contribute to future control.
\end{abstract}

\section{Keywords}

\section{HAV, Oyster, IA Genogroup}

\section{Introduction}

A wide variety of human enteric viruses may be found as food and waterborne virus [1]. Among them, Hepatitis A virus (HAV) and Norovirus (NoV) become the main targets of virus detection in food [1]-[3]. HAV is mainly transmitted via the fecal-oral route, and the incidence of HAV is strongly correlated with contaminated water and food [4].

HAV is foodborne and waterborne enteric virus that can cause acute hepatitis in human [2] [3]. Foods of primary importance are bivalve shellfish, particularly; oysters have caused outbreaks after being contaminated by polluted water or virus-infected food handlers [2] [5].

HAV infection has become an important public health problem in industrialized countries such as Korea, the 
improved hygienic and sanitary conditions, and the application of public health measures have led to a decline seroprevalence of anti-HAV in childhood [6] [7], whereas the incidence of obvious acute hepatitis A has recently been increasing in adults [8]-[10]. This information is important for the prevention of food poisoning caused by HAV.

The aim of the present study was to investigate the prevalence and contamination of HAV by nested RT-PCR and to investigate phylogenetic analysis of circulating HAV strains detected from oyster in Korea.

\section{Materials and Methods}

\subsection{Shellfish Samples}

All shellfish used in this study were collected from commercial market areas in Seoul during 2011 to 2012. Altogether, 56 samples of oysters were used. For each sample a minimum of six shellfish were aseptically opened, and the animals were removed from their shells. To degrade the shellfish tissue and allow the release of virions into solution, an equal volume of a Proteinase K $(30 \mathrm{U} / \mathrm{mg})$ was carried at $320 \mathrm{rpm}$ for $60 \mathrm{~min}$. The reaction mixture was subsequently incubated at $62^{\circ} \mathrm{C} \pm 2.0^{\circ} \mathrm{C}$ for $15 \mathrm{~min}$ in order to inactivate the proteinase, and the soluble portion (shellfish concentrate) was collected by centrifugation at $4000 \mathrm{~g}$ for $5 \mathrm{~min}$ and recollected by centrifugation at $4000 \mathrm{~g}$ for $2 \mathrm{~min}$. This proteinase $\mathrm{K}$ digestion method was modified [11].

\subsection{RNA Isolation}

Viral RNA was isolated directly from the digestive tissue. Nucleic acid was extracted from $200 \mu \mathrm{l}$ of from the digestive tissue using the QIAamp Viral RNA mini kit (Qiagen, Hilden, Germany) according to the manufacturer's instructions. The viral RNA was finally eluted from the spin column in $50 \mu$ of elution buffer and stored at $-70^{\circ} \mathrm{C}$.

\subsection{RT-PCR for Enteric Viruses}

The viral RNA was finally eluted from the spin column in $50 \mu \mathrm{l}$ of elution buffer and stored at $-70^{\circ} \mathrm{C}$. RT-PCR and Nested PCR were carried with described previously shown in Table 1.

Table 1. Primers used for detection of enteric viruses using conventional RT-PCR.

\begin{tabular}{|c|c|c|c|c|c|}
\hline Viruses & Primer & Sequence(5’-3’) & Position (nt) & Size (bp) & Reference \\
\hline \multirow[t]{3}{*}{ Norovirus GI } & GI-F1M & CTGCCCGAATTYGTAAATGAT & 5336-5359 & \multirow{3}{*}{314} & \multirow{3}{*}[12]{} \\
\hline & GI-R1M & CCAACCCARCCATTRTACATYTG & 5643-5665 & & \\
\hline & GI-F2 & ATGATGATGGCGTCTAAGGACGC & $5352-5374$ & & \\
\hline \multirow[t]{3}{*}{ Norovirus GII } & GII-F1M & GGGAGGGCGATCGCAATCT & $5049-5067$ & \multirow{3}{*}{313} & \multirow{3}{*}{ [12] } \\
\hline & GII-R1M & CCRCCIGCATRICCRTTRTACAT & $5367-5389$ & & \\
\hline & GII-F3M & TTGTGAATGAAGATGGCGTCGART & $5077-5100$ & & \\
\hline \multirow[t]{2}{*}{ Astrovirus } & Mon340 & CGTCATTATTTGTTGTCATACT & $1182-1203$ & \multirow{2}{*}{289} & \multirow{2}{*}{ [13] } \\
\hline & Mon348 & ACATGTGCTGCTGTTACTATG & $1450-1470$ & & \\
\hline \multirow[t]{2}{*}{ Sapovirus } & SLV5317 & CTCGCCACCTACRAWGCBTGGTT & $5083-5105$ & \multirow{2}{*}{434} & \multirow{2}{*}{ [14] } \\
\hline & SLV5749 & CGGRCYTCAAAVSTACСВССССА & $5516-5494$ & & \\
\hline \multirow[t]{4}{*}{ Hepatitis A virus } & BR-9b & AGTCACACCTCTCCAGGAAAACTT & 2950-2972 & \multirow{2}{*}{361} & \multirow{4}{*}{ [15] } \\
\hline & BR-5b & TTGTCTGTCACAGAACAATCAG & 3310-3333 & & \\
\hline & $\mathrm{RJ}-3 \mathrm{c}$ & TCCCAGAGCTCCATTGAA & 2984-3001 & \multirow{2}{*}{234} & \\
\hline & $\mathrm{Br}-6 \mathrm{~b}$ & AGGAGGTGGAAGCACTTCATTTGA & $3217-3240$ & & \\
\hline
\end{tabular}




\subsection{ELISA for RoV and AdV}

Detection of RoV and AdV antigen in the samples was carried out by ELISA using the BioTracer ${ }^{\mathrm{TM}}$ Adenovirus and Rotavirus kit (BioFocus, Korea) in accordance with the manufacturer's instructions.

\subsection{Nucleotide Sequencing for HAV}

RT-PCR products were purified using a QIAquick Gel Extraction Kit (Qiagen, Hilden, Germany). Analyses of nucleotide sequences were carried out by Cosmogentec (Korea) using the Big Dye Dideoxy cycle sequencing kit and the ABI PRISM 3730XL Analyzer (Applied Biosystem, USA). The virus subtype was determined by phylogenetic analysis of 158 nucleotides from the VP1/2A junction using the Neighbor Joining algorithm with the Kimura two-parameter model with 1000 bootstrap for genotypic strain classification of the MEGA 4 program [16]. Sequences were compared with available sequences in GenBank using the BlAST program of the National Center for Biotechnology Information (NCBI).

\section{Results}

Using the semi-nested RT-PCRs, HAV was detected on oyster by RT-PCR in 19.6\% (11/56) in Korea. The percentages of HAV-positive samples in 2011 and 2012 were 27.6\% and 11.1\%, respectively. Other enteric Viruses were not detected in Oyster in Korea.

Amplicons from oysters were electrophoresed for comparison with corresponding HAV protostrains (Figure 1). All amplicons of HAVs from oysters were sequenced successfully. Phylogenetic analysis of the coding regions of the viral protein VP4/VP2 revealed that all amplicons were classified into IA genogroup I, these strains could be subdivided into 2 clusters of genogroup IA and genogroup IB.

Using the BLAST program and phylogenetic analysis, the DNA sequence showed 99.3\% nucleotide sequence identity with AB038293, EU073738, and GU991276 within the same cluster as the reference strain (AY322886).

\section{Discussion}

The viruses primarily associated with shellfish-borne illness are norovirus, causing gastroenteritis and HAV [17]. A large variety of oyster and raw shellfish have been associated with transmission of viral disease [18]-[20].

Previous studies have shown that eating raw shellfish was shown to be a significant predictor of HAV infection in the multivariate analysis [21] and eating raw shellfish significantly increased the odds ratio of HAV infection in an Italian study [22]. As reported from other parts of the world, most studies support the correlation between eating raw shellfish and the risk of hepatitis A infection [2] [17] [23] [24].

To date, there are no reports of HAV related with the consumption of the oyster originated from Korea. Therefore, to protect the consumer, it is very important to inform the prevalence of HAV in oyster.

In the present study, the detection rate for HAV was $19.6 \%$ in oysters. The prevalence of HAV contamination observed in this and in other studies appears to be subjected to a certain variation. In South Italy, the prevalence of HAV in shellfish was 18.2\% [25], while in another study in Spain, the prevalence of HAV in 45 shellfish was $27.4 \%$ [26]. In three year study of the southern France, the prevalence of HAV in oysters was 13\% [27]. The discrepancy of the HAV prevalence in shellfish rates between our study and others might be due to the difference in the season and/or geographical area where those studies have been conducted. Our result shows that HAV contamination is seems to be slightly higher than that previously reported in other studies.

Previous studies have shown that the majority of the reported outbreaks were located in East Asia, followed by Europe, America, Oceania, Australia and Africa. More than half of the outbreaks (63.6\%) have been published in Japan. The most common viral pathogens involved were NoV (83.7\%) and HAV (12.8\%). The most frequent type of consumed shellfish which was involved outbreaks was oysters (58.4\%) [28]. Outbreaks of viral diseases (HAV, NoV) are frequently associated with the consumption of minimally processed shellfish [29] [30]. Shellfish consumption in Korea is a major risk factor for HAV infection [31], since these products are commonly eaten raw or slightly cooked. Only a drastic heat treatment can assure a complete inactivation of virus [32] and only through cooking of shellfish can reduce the risk to human health [25]. This makes clear the potential to public concern about shellfish safety.

Sequencing is very important for outbreak investigations to provide evidence of the source of the outbreak in 


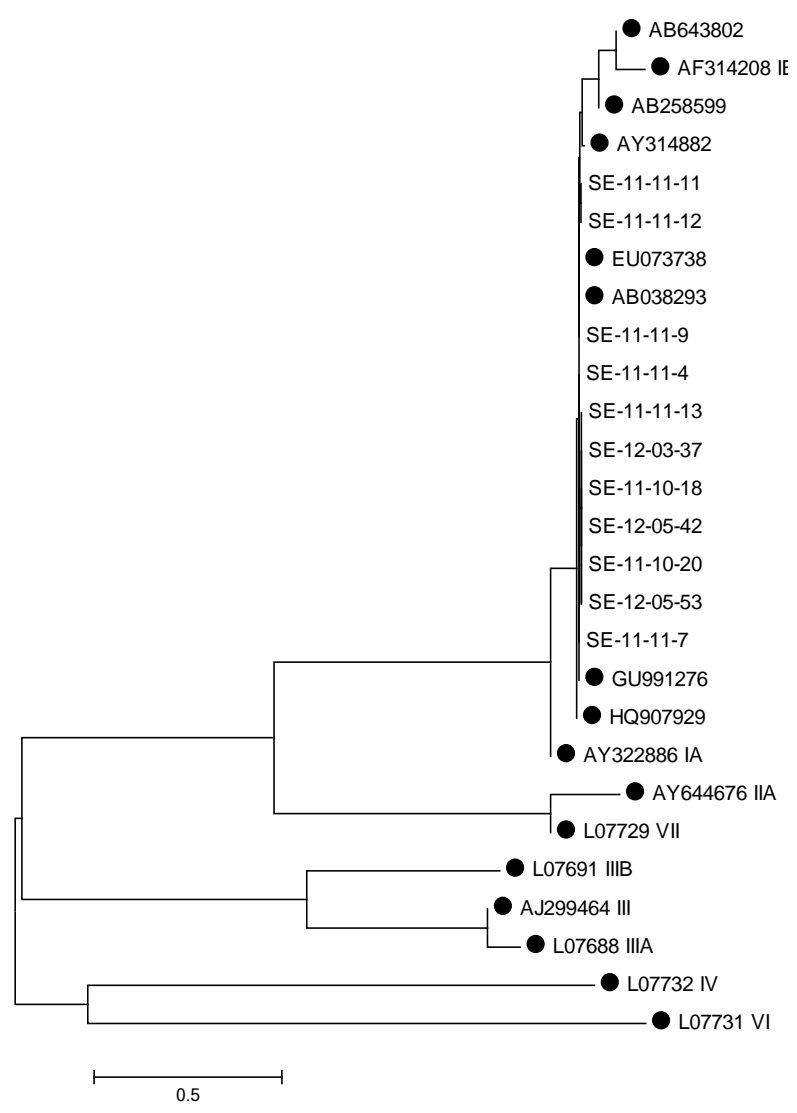

Figure 1. Phylogenetic analysis of identified HAVs based on GII (159 bp VP1/2A region), HAV references are indicated by the shaded black circles. The percentage bootstrap values were observed among the 1,000 replicates indicated. There are sixteen reference strains from GenBank (AB643802, AF314208, AB258599, AY314882, EU073738, AB038293, GU991276, HQ907729, AY322886, AY644676, LO7729, LO7691, AJ299464, LO7688, LO7732, and LO7731).

combination with a national surveillance system. Sequence analysis showed that the identified HAV strains are most closely related to Korea isolate (EU073738) and Japan isolate (AB038293). Nucleotide sequences of a segment in the VP1/2A junction indicate that this is a genotype I virus. This is not surprising, since approximately $80 \%$ of the human HAV strains isolated are type I, with most remaining human strains being type III [33]-[35]. Subgenotypes IA and IB are the most common found in Brazil, France, China, and Japan [36]. In this study, however, HAV sequences were classified as genotype IA which is endemic in North America [37]. Another interesting feature of the study were classified as genotype IB which is bivalves in Italy [38] and outbreak of HAV in the USA associated with frozen pomegranate arils [37]. Virus genotype IB illnesses associated with food from the Middle East, Egypt, and Morocco [39]-[41]. All of the 11 isolates of HAV demonstrated a high identity (from $98.7 \%$ to $100 \%$ ) to each other suggested that they probably came from the same source of infection. The utilization of sequence information can allow surveillance of recent isolates to determine whether this strain has been, or is, entering from other countries.

Vaccination against HAV should be part of a comprehensive plan for the prevention and control of viral hepatitis [42]. In the Korea, HAV vaccination has been recommended for all children aged 12 - 23 months since 2015. And the number of acute cases might be fallen. In non-endemic areas HAV may be a relatively rare contaminant in bivalve shellfish because of low levels in the community. However, the disease is more severe than norovirus and the consequences of an outbreak can be dramatic [43]-[45]. Thus, HAV is also targeted by the standard [7]. In 2007, the Korean Society of Infectious Diseases recommended that all adults in their 20s should 
be vaccinated against hepatitis $\mathrm{A}$, as well as adults in their 30s and 40s without immunity [46]. It should be noted that immunization for adult who is likely to eat raw oyster or handle food ingredients occupationally or travel overseas to HAV-endemic areas is needed to prevent spreading from an outbreak caused by HAV [21].

\section{Conclusion}

In conclusion, these results will be useful data for the prevention of food poisoning caused by HAV and food safety regulation government related institute for the prevention and control of HAV in Korea.

\section{References}

[1] Fuentes, C., Guix, S., Pérez-Rodriguez, F.J., Fuster, N., Carol, M., Pintó, R.M. and Bosch, A. (2014) Standardized Multiplex One-Step qRT-PCR for Hepatitis A Virus, Norovirus GI and GII Quantification in Bivalve Mollusks and Water. Food Microbiology, 40, 55-63. http://dx.doi.org/10.1016/j.fm.2013.12.003

[2] Bosch, A., Sanchez, G., Abbaszadegan, M., Carducci, A., Guix, S., Le Guyader, F.S., Netshikweta, R., Pinto, R.M., van der Poel, W.H.M., Rutjes, S., Sano, D., Taylor, M.B., van Zyl, W.B., Lazaro, D.R., Kovac, K. and Sellwood, J. (2011) Analytical Methods for Virus Detection in Water and Food. Food Analytical Methods, 4, 4-12. http://dx.doi.org/10.1007/s12161-010-9161-5

[3] Koopmans, M., von Bonsdorff, C.H., Vinjé, J., de Medici, D. and Monroe, S. (2002) Foodborne Viruses. FEMS Microbiology Reviews, 26, 187-205. http://dx.doi.org/10.1111/j.1574-6976.2002.tb00610.x

[4] Fiore, A.E. (2004) Hepatitis A Transmitted by Food. Clinical Infectious Diseases, 38, 705-715. http://dx.doi.org/10.1086/381671

[5] Namsai, A., Louisirirotchanakul, S., Wongchinda, N., Siripanyaphinyo, U., Virulhakul, P., Puthavathana, P., Myint, K.S., Gannarong, M. and Ittapong, R. (2011) Surveillance of Hepatitis A and E Viruses Contamination in shellfish in Thailand. Letters in Applied Microbiology, 53, 608-613. http://dx.doi.org/10.1111/j.1472-765X.2011.03152.X

[6] Lim, J., Song, Y.J., Park, W.S., Sohn, H., Lee, M.S., Shin, D.H., Kim, C.B., Kim, H., Oh, G.J. and Ki, M. (2014) The immunogenicity of a Single Dose of hepatitis A virus vaccines (Havrix ${ }^{\circledR}$ and Epaxal ${ }^{\circledR}$ ) in Korean Young Adults. Yonsei Medical Journal, 55, 126-131. http://dx.doi.org/10.3349/ymj.2014.55.1.126

[7] Sohn, Y.M., Rho, H.O. and Park, M.S. (2000) The Changing Epidemiology and Hepatitis A on Children and the Consideration of Active Immunization in Korea. Yonsei Medical Journal, 41, 34-39. http://dx.doi.org/10.3349/ymj.2000.41.1.34

[8] Kang, J.H., Lee, K.Y., Kim, C.H. and Sim, D. (2004) Changing Hepatitis A Epidemiology and the Need for Vaccination in Korea. Asian Pacific Journal of Allergy and Immunology, 22, 237-242.

[9] Song, M.H., Lim, Y.S., Song, T.J., Choi, J.M., Kim, J.I., Jun, J.B., Kim, M.Y., Pyun, D.K., Lee, H.C., Jung, Y.H., Lee, Y.S. and Suh, D.J. (2005) The Etiology of Acute Viral Hepatitis for the Last 3 Years. Journal of Korean Medical Science, 68, 256-260.

[10] Lee, T.H., Kim, S.M., Lee, G.S., Im, E.H., Huh, K.C., Choi, Y.W. and Kang, Y.W. (2006) Clinical Features of Acute Hepatitis A in the Western Part of Daejeon and Chungnam Province; Single Center Experience. The Korean Journal of Gastroenterology, 47, 136-143.

[11] Jothikumar, N., Lowther, J.A., Henshilwood, K., Lees, D.N., Hill, V.R. and Vinjé, J. (2005) Rapid and Sensitive Detection of Noroviruses by Using TaqMan-Based One-Step Reverse Transcription-PCR Assays and Application to Naturally Contaminated Shellfish Samples. Applied and Environmental Microbiology, 71, 1870-1875. http://dx.doi.org/10.1128/AEM.71.4.1870-1875.2005

[12] Kim, S.H., Cheon, D.S., Kim, J.H., Lee, D.H., Jheong, W.H., Heo, Y.J., Chung, H.M., Jee, Y. and Lee, J.S. (2005) Outbreaks of Gastroenteritis That Occurred during School Excursions in Korea Were Associated with Several Waterborne Strains of Norovirus. Journal of Clinical Microbiology, 43, 4836-4839. http://dx.doi.org/10.1128/JCM.43.9.4836-4839.2005

[13] Belliot, G., Laveran, H. and Monroe, S.S. (1997) Detection and Genetic Differentiation of Human Astroviruses: Phylogenetic Grouping Varies by Coding Region. Archives of Virology, 142, 1323-1334. http://dx.doi.org/10.1007/s007050050163

[14] Yan, H., Yagyu, F., Okitsu, S., Nishio, O. and Ushijima, H. (2003) Detection of Norovirus (GI, GII), Sapovirus and Astrovirus in Fecal Samples Using Reverse Transcription Single-Round Multiplex PCR. Journal of Virological Methods, 114, 37-44. http://dx.doi.org/10.1016/j.jviromet.2003.08.009

[15] Hussain, Z., Das, B.C., Husain, S.A., Asim, M., Chattopadhyay, S., Malik, A., Poovorawan, Y., Theamboonlers, A. and Kar, P. (2005) Hepatitis A Viral Genotypes and Clinical Relevance: Clinical and Molecular Characterization of Hepatitis A Virus Isolates from Northern India. Hepatology Research, 32, 16-24. 
http://dx.doi.org/10.1016/j.hepres.2005.01.014

[16] Tamura, K., Dudley, J., Nei, M. and Kumar, S. (2007) MEGA4: Molecular Evolutionary Genetics Analysis (MEGA) Software Version 4.0. Molecular Biology and Evolution, 24, 1596-1599. http://dx.doi.org/10.1093/molbev/msm092

[17] Lees, D. (2010) International Standardization of a Method for Detection of Human Pathogenic Viruses in Molluscan. Food and Environmental Virology, 2, 146-155. http://dx.doi.org/10.1007/s12560-010-9042-5

[18] Jaykus, L.A., Hemard, M.T. and Sobsey, M.D. (1994) Human Enteric Pathogenic Viruses. In: Hackney, C.R. and Pierson, M.D., Eds., Environmental Indicators and Shellfish Safety, Chapman and Hall, New York, 92-153. http://dx.doi.org/10.1007/978-1-4615-2035-1_3

[19] Shieh, Y.S.C., Monroe, S.S., Frankhauser, R.L., Langlois, G.W., Burkhardt, W. and Baric, R.S. (2000) Detection of Norwalk-Like Viruses in Shellfish Implicated in Illness. The Journal of Infectious Diseases, 181, 360-367. http://dx.doi.org/10.1086/315578

[20] Widdowson, M.A., Cramer, E.H., Hadley, L., Bresee, J.S., Beard, R.S., Bulens, S.N., Charles, M., Chege, W., Isakbaeva, E., Wright, J.G., Mintz, E., Forney, D., Massey, J., Glass, R.I. and Monroe, S.S. (2004) Outbreaks of Acute Gastroenteritis Oncruise Ships and on Land: Identification of a Predominant Circulating Strain of Norovirus-United States. The Journal of Infectious Diseases, 190, 27-36. http://dx.doi.org/10.1086/420888

[21] Seo, J.Y., Choi, B.Y., Ki, M., Jang, H.L., Park, H.S., Son, H.J., Bae, S.H., Kang, J.H., Jun, D.W., Lee, J.W., Hong, Y.J., Kim, Y.S., Kim, C.H., Chang, U.I., Kim, J.H., Yang, H.W., Kim, H.S., Park, K.B., Hwang, J.S., Heo, J., Kim, I.H., Kim, J.S. and Cheon, G.J. (2013) Risk Factors for Acute Hepatitis a Infection in Korea in 2007 and 2009: A CaseControl Study. Journal of Korean Medical Science, 28, 908-914. http://dx.doi.org/10.3346/jkms.2013.28.6.908

[22] Tosti, M.E., Spada, E., Romanò, L., Zanetti, A. and Mele, A., SEIEVA Collaborating Group (2008) Acute Hepatitis A in Italy: Incidence, Risk Factors and Preventive Measures. Journal of Viral Hepatitis, 15, 26-32. http://dx.doi.org/10.1111/j.1365-2893.2008.01025.x

[23] Koopmans, M. and Duizer, E. (2004) Foodborne Viruses: An Emerging Problem. International Journal of Food Microbiology, 90, 23-41. http://dx.doi.org/10.1016/S0168-1605(03)00169-7

[24] Widdowson, M.A., Sulka, A., Bulens, S.N., Beard, R.S., Chaves, S.S., Hammond, R., Salehi, E.D., Swanson, E., Totaro, J., Woron, R., Mead, P.S., Bresee, J.S., Monroe, S.S. and Glass, R.I. (2005) Norovirus and Foodborne Disease, United States, 1991-2000. Emerging Infectious Diseases, 11, 95-102. http://dx.doi.org/10.3201/eid1101.040426

[25] Chironna, M., Germinario, C., De Medici, D., Fiore, A., Di Pasquale, S., Quarto, M. and Barbuti, S. (2002) Detection of Hepatitis A Virus in Mussels from Different Sources Marketed in Puglia Region (South Italy). International Journal of Food Microbiology, 75, 11-18. http://dx.doi.org/10.1016/S0168-1605(01)00743-7

[26] Romalde, J.L., Area, E., Sánchez, G., Ribao, C., Torrado, I., Abad, X., Pintó, R.M., Barja, J.L. and Bosch, A. (2002) Prevalence of Enterovirus and Hepatitis A Virus in Bivalve Molluscs from Galicia (NW Spain): Inadequacy of the EU Standards of Microbiological Quality. International Journal of Food Microbiology, 74, 119-130. http://dx.doi.org/10.1016/S0168-1605(01)00744-9

[27] Le Guyader, F., Haugarreau, L., Miossec, L., Dubois, E. and Pommepuy, M. (2000) Three-Year Study to Assess Human Enteric Viruses in Shellfish. Applied and Environmental Microbiology, 66, 3241-3428. http://dx.doi.org/10.1128/AEM.66.8.3241-3248.2000

[28] Bellou, M., Kokkinos, P. and Vantarakis, A. (2013) Shellfish-Borne Viral Outbreaks: A Systematic Review. Food Environmental Virology, 5, 13-23. http://dx.doi.org/10.1007/s12560-012-9097-6

[29] Ha, J.H., Choi, C. and Ha, S.D. (2014) Evaluation of Immunomagnetic Separation Method for the Recovery of Hepatitis A Virus and GI.1 and GII.4 Norovirus Strains Seeded on Oyster and Mussel. Food Environmental Virology, 6, 290296. http://dx.doi.org/10.1007/s12560-014-9156-2

[30] Lees, D. (2000) Viruses and Bivalve Shellfish. International Journal of Food Microbiology, 49, 81-116. http://dx.doi.org/10.1016/S0168-1605(00)00248-8

[31] Ko, S.M., Vaidya, B., Kwon, J., Lee, H.M., Oh, M.J., Shin, T.S., Cho, S.Y. and Kim, D. (2015) Detection of Hepatitis A Virus in Seeded Oyster Digestive Tissue by Ricin A-Linked Magnetic Separation Combined with Reverse Transcription PCR. Journal of Food Protection, 78, 1046-1051. http://dx.doi.org/10.4315/0362-028X.JFP-14-540

[32] Croci, L., De Medici, D., Morace, G., Fiore, A., Scalfaro, C., Beneduce, F. and Toti, L. (1999) Detection of Hepatitis A Virus in Shellfish by Nested Reverse Transcription-PCR. International Journal of Food Microbiology, 48, 67-71. http://dx.doi.org/10.1016/S0168-1605(99)00028-8

[33] Ishii, K., Kiyohara, T., Yoshizaki, S., Wakita, T., Shimada, T., Nakamura, N., Nakashima, K., Tada, Y. and Noda, M. (2012) Epidemiological and Genetic Analyses of a Diffuse Outbreak of Hepatitis A in Japan, 2010. Journal of Clinical Microbiology, 53, 219-224.

[34] Li, K.K., Penrice, G.M. and Gunson, R.N. (2015) An Outbreak of Hepatitis A Virus Associated with a Multi-National Inner-City Nursery in Glasgow, Scotland. Journal of Clinical Virology, 69, 12-15. 
http://dx.doi.org/10.1016/j.jcv.2015.05.011

[35] Yun, H., Kim, S., Lee, H., Byun, K.S., Kwon, S.Y., Yim, H.J., Lim, Y.S., Jeong, S.H. and Jee, Y. (2008) Genetic Analysis of HAV Strains Isolated from Patients with Acute Hepatitis in Korea, 2005-2006. Journal of Medical Microbiology, 80, 777-784. http://dx.doi.org/10.1002/jmv.21127

[36] Lee, A.R., Lee, S.G., Kang, L.H., Jheong, W.H. and Paik, S.Y. (2013) Full-Length Genomic Sequence of Subgenotype IIIA Hepatitis A Virus Isolate in Republic of Korea. Journal of Biomedicine and Biotechnology, 2013, 1-11. http://dx.doi.org/10.1155/2013/426034

[37] Pahil, S., Goyal, K. and Singh, M.P. (2015) Hepatitis A Outbreaks. The Lancet Infectious Diseases, $15,634$. http://dx.doi.org/10.1016/S1473-3099(15)00022-5

[38] Iaconelli, M., Purpari, G., Libera, S.D., Petricca, S., Guercio, A., Ciccaglione, A.R., Bruni, R., Taffon, S., Equestre, M., Fratini, M., Muscillo, M. and La Rosa, G. (2015) Hepatitis A and E Viruses in Wastewaters, in River Waters, and in Bivalve Molluscs in Italy. Food Environmental Virology, 7, 316-324. http://dx.doi.org/10.1007/s12560-015-9207-3

[39] Faber, M.S., Stark, K., Behnke, S.C., Schreier, E. and Frank, C. (2009) Epidemiology of Hepatitis A Virus Infections, Germany, 2007-2008. Emerging Infectious Diseases, 15, 1760-1768. http://dx.doi.org/10.3201/eid1511.090214

[40] Nejati, A., Makvandi, M., Samarbafzadeh, A., Neisi, N. and Moradzadegan, H. (2012) Molecular Epidemiology of Hepatitis A Virus in Patients in the Ahwaz Region of Iran. Journal of Medical Microbiology, 84, 582-586.

[41] Normann, A., Badur, S., Onel, D., Kilic, A., Sidal, M., Larouzé, B., Massari, V., Müller, J. and Flehmig, B. (2008) Acute Hepatitis A Virus Infection in Turkey. Journal of Medical Microbiology, 80, 785-790. http://dx.doi.org/10.1002/jmv.21137

[42] No Authors Listed (2012) WHO Position Paper on Hepatitis A Vaccines—June 2012. The Weekly Epidemiological Record, 87, 261-276.

[43] Bosch, A., Sánchez, G., Le Guyader, F., Vanaclocha, H., Haugarreau, L. and Pintó, R.M. (2001) Human Enteric Viruses in Coquina Clams Associated with a Large Hepatitis A Outbreak. Water Science and Technology, 43, 61-65.

[44] Conaty, S., Bird, P., Bell, G., Kraa, E., Grohmann, G. and McAnulty, J.M. (2000) Hepatitis A in New South Wales, Australia from Consumption of Oysters: The First Reported Outbreak. Epidemiology and Infection, 124, 121-130. http://dx.doi.org/10.1017/S0950268899003386

[45] Shieh, Y.C., Khudyakov, Y.E., Xia, G., Ganova-Raeva, L.M., Khambaty, F.M., Woods, J.W., Veazey, J.E., Motes, M.L., Glatzer, M.B., Bialek, S.R. and Fiore, A.E. (2007) Molecular Confirmation of Oysters as the Vector for Hepatitis A in a 2005 Multistate Outbreak. Journal of Food Protection, 70, 145-150.

[46] Cheong, H.J. (2011) Vaccination Necessary for Korean Adults. Journal of Korean Medical Science, 54, $1289-1296$. http://dx.doi.org/10.5124/jkma.2011.54.12.1289 